FOLIA POMERANAE UNIVERSITATIS TECHNOLOGIAE STETINENSIS

Folia Pomer. Univ. Technol. Stetin., Oeconomica 2017, 339(89)4, 55-62

EIwira LEŚNA-WIERSZOŁOWICZ

\title{
APPLICATION OF CORPORATE SOCIAL RESPONSIBILITY CONCEPT IN THE ACTIVITY OF PKN ORLEN GROUP
}

\section{WYKORZYSTANIE KONCEPCJI SPOKECZNEJ ODPOWIEDZIALNOŚCI BIZNESU W DZIAŁALNOŚCI GRUPY KAPITAŁOWEJ POLSKI KONCERN NAFTOWY ORLEN}

Department of System Analysis and Finance, West Pomeranian University of Technology, Szczecin Klemensa Janickiego 31, 71-270 Szczecin, Poland, e-mail: elesna@zut.edu.pl

\begin{abstract}
Streszczenie. Celem artykułu jest przedstawienie koncepcji społecznej odpowiedzialności biznesu w działalności Grupy Kapitałowej PKN ORLEN. W artykule przedstawiono istotę, wymiary i obszary CSR oraz korzyści z jej realizacji. Uzupełnieniem artykułu jest opis dobrych praktyk podejmowanych przez Grupę Kapitałową PKN ORLEN, dla której odpowiedzialność społeczna jest istotnym elementem strategii biznesowej.
\end{abstract}

Key words: corporate social responsibility, CSR, benefits of corporate social responsibility, good practices.

Słowa kluczowe: społeczna odpowiedzialność biznesu, CSR, korzyści z wdrożenia koncepcji społecznej odpowiedzialności biznesu, dobre praktyki.

\section{INTRODUCTION}

Corporate Social Responsibility (CSR) is a concept according to which organizations take into account, on a voluntary basis, the interests of society, the environment and various stakeholder groups at the stage of strategy building. Socially responsible business brings benefits to the company and to the environment in which it operates. The concept of CSR influences not only the image of the company, but also the relationship of the company with different stakeholder groups (Leśna-Wierszołowicz 2016a).

The aim of the paper is to present how the concept of corporate social responsibility in implemented by PKN ORLEN which is a leading company in Polish fuel and energy sector.

\section{THE DEFINITION OF CORPORATE SOCIAL RESPONSIBILITY}

Over the years many definitions of corporate social responsibility have been formulated. Most definitions of corporate social responsibility describe it as a concept whereby companies integrate social and environmental concerns in their business actions and in their interaction with their stakeholders on a voluntary basis. The term "corporate social responsibility" has been present in academic literature and dates back to the 1950s. In 1953 Howard R. Bowen in his book Social Responsibility of Businessman wrote „social responsibility 
represents entrepreneurs" commitment to strive to use such strategies, make such decisions or perform such activities that our goals and our society require (Żurek 2013). Howard R. Bowen is considered to be the first theoretician of corporate social responsibility. According to Bowen, corporate social responsibility will not solve all global issues, but it entails an important truth which should become a founding principle of businesses that guide them towards the future (Čierna 2015).

The European Commission claims that CSR is a concept "whereby companies decide voluntarily to contribute to a better society and a cleaner environment" (Commission of the European Communities 2001). What is more, being socially responsible means not only fulfilling legal expectations, but also going beyond compliance and investing more into human capital, the environment and the relations with stakeholders. Going beyond basic legal obligations in the social area can also have a direct impact on company's productivity and competitiveness (Commission of the European Communities 2001). There is today a growing perception among enterprises that sustainable business success and shareholder value cannot be achieved solely through maximizing short-term profits, but instead through market-oriented yet responsible behaviour. Companies are aware that they can contribute to sustainable development by managing their operations in such a way as to enhance economic growth and increase competitiveness whilst ensuring environmental protection and promoting social responsibility, including consumer interests (Commission of the European Communities 2002).

According to Rok (2004), a responsible business:

- achieves sustainable profits while developing positive relationships with all stakeholders;

- is a management tool that allows to use the process of building dialogue with stakeholders to improve business development strategy;

- is a business philosophy based on building lasting, transparent relationships with all stakeholders: employees, customers, suppliers, shareholders, competitors and the local community;

- is related to building a strategy of competitive advantage in the market, based on providing lasting value not only for shareholders, but also other stakeholders;

- related to provision of services and products in a way that does not degrade the natural and social environment;

- takes into account ethical values, law, respect for employees, society and the natural environment;

- is guided by integrity and fair business practices,

- is conducted in accordance with social expectations, which are ethical, legal, financial and civic;

- develops and implements a social commitment strategy that exceeds legal obligations for the benefit of all citizens, in line with socially accepted ethical standards;

- is managed in such a way that economic effects are consistent with social values;

- contributes to sustainable development through cooperation with workers, the local community and the global community to improve the quality of life for all citizens;

- is pervaded by a sense of responsibility for the consumer, the investor, the society, the natural environment, the success of the economy; 
- considers social, ethical and environmental aspects in its operations and contacts with stakeholders;

- uses transparent business practices, based on respect for employees, communities and the environment.

\section{DIMENSIONS AND AREAS OF CORPORATE SOCIAL RESPONSIBILITY}

Corporate social responsibility manifests itself in everyday business practice in two dimensions: internal and external (Rok 2004).

The internal dimension refers to:

- human resources management (e.g. employee empowerment, better exchange of information between employees and management staff, involvement of employees in decision-making processes, development perspectives and skills development, fair wages, support for reconciling work and family life, employee training);

- ethics programs for employees (e.g. ethical codes, ethics training, ethics code violations);

- health and safety at work (in addition to the required workplace safety rules in the company, various forms of health care for employees);

- ability to adapt to changes (e.g. taking into account the interests of all parties in case of restructuring, to minimize its negative effects, flexibility of employment, dismissal rules);

- the impact of the company on the environment (e.g. reduction of energy consumption, water, waste management and, above all, procedures allowing for a systematic reduction of the company's negative environmental impact);

- corporate governance principles (e.g. transparency of information, methods of appointing and remunerating members of supervisory boards, investments in sustainable development).

The external dimension embraces:

- positive impact on the local community (e.g. volunteering, involvement in philanthropic activities, social effects of business activities, creating jobs for the disabled, civic engagement, social investments);

- relationships with trading partners, suppliers and customers (e.g. timely delivery of supplies and payments to counterparts, efficient response to customer complaints, taking into account social and environmental aspects in trade decisions, delivering products and services that are environment-friendly and environmentally safe);

- respect for human rights (e.g. non-employment of children, equal opportunities, fair trade),

- environmental concerns (e.g. use of technologies that reduce the consumption of non-renewable resources, use of renewable sources in meeting energy needs).

Areas of CSR, the stakeholder groups assigned to them and their expectations arising from the strategy of responsible business are presented in Table 1.

An organization committed to corporate social responsibility takes into account interests of all its stakeholders in every area of its business, and demonstrates respect for stakeholder expectations which is a matter of good will and is not subject to any formal regulations. 
Table 1. Areas of CSR

\begin{tabular}{|l|l|l|}
\hline \multicolumn{1}{|c|}{ Areas of CSR } & \multicolumn{1}{|c|}{ Groups of stakeholders } & \multicolumn{1}{c|}{ Actions } \\
\hline Market environment & $\begin{array}{l}\text { suppliers, recipients, contractors, co-workers, } \\
\text { competitors }\end{array}$ & $\begin{array}{l}\text { applying ethics in dealing with the } \\
\text { environment, honest information and } \\
\text { advertising practices, integrity in all } \\
\text { operations, in particular privatization } \\
\text { processes, mergers and acquisitions }\end{array}$ \\
\hline Public environment & $\begin{array}{l}\text { public administration, non-governmental } \\
\text { organizations, public benefit organizations } \\
\text { and non-profit institutions }\end{array}$ & $\begin{array}{l}\text { active participation in science, culture, } \\
\text { education and health }\end{array}$ \\
\hline Employment & human resources management & $\begin{array}{l}\text { respect for social justice, giving } \\
\text { opportunities for personal development, } \\
\text { ensuring stability and safety in the } \\
\text { workplace }\end{array}$ \\
\hline Environmental Protection & $\begin{array}{l}\text { technology and planning activities related } \\
\text { to the use of natural resources }\end{array}$ & $\begin{array}{l}\text { a good economy with limited natural } \\
\text { resources in the enterprise, compliance } \\
\text { with environmental regulations }\end{array}$ \\
\hline Relationships with investors & current and future shareholders & $\begin{array}{l}\text { providing investors with reliable, } \\
\text { complete and up-to-date information, } \\
\text { respect for pre-emption rights, com- } \\
\text { pliance with agreements, promises } \\
\text { and declarations }\end{array}$ \\
\hline
\end{tabular}

Source: Marcinkowska et al. (2016).

\section{BENEFITS OF IMPLEMENTING THE CONCEPT OF CORPORATE SOCIAL RESPONSIBILITY}

The long-term benefits of adopting CSR are as follows (Rak 2017):

- winning the interest of investors and enhancing company credibility and transparency, which increases confidence in an organization (also among lenders);

- growth in customer and other stakeholder loyalty;

- building and maintaining favourable relations with the community and local administration in result of involvement in social activities benefitting the local community;

- improved competitive edge of an organization thanks to enhanced brand image and reputation;

- shaping the enterprise's organizational culture by enhancing the value of cooperation between stakeholders and building a partnership;

- building a good company image and attractiveness as an employer among existing and potential employees by using CSR actions as instruments of non-financial employee motivation.

Responsible business practices bring measurable benefits to the company and the society. The benefits to the company can be divided into internal (i.e. connected to relationships within the organization) and external (i.e. relating to the company's environment) (Wykowski 2013).

Internal benefits include:

- increased employee involvement and motivation,

- improved organizational culture,

- lower supervision costs,

- increased innovation,

- marketing benefits. 
External benefits include:

- bolstered positive image in the eyes of stakeholders,

- aligning with local community's interests, prevention of conflict,

- increased number of loyal customers,

- enhanced competitiveness,

- improved investor interest,

- increased local prestige and status earned by involvement in charity.

Major benefits to the society include:

- active participation of enterprises in solving social problems,

- environmental protection,

- activation of the local community,

- educational programs for residents,

- the possibility of using staff time (volunteering),

- financing of sports, cultural and charity activities.

\section{GOOD PRACTICES UNDERTAKEN BY PKN ORLEN GROUP}

PKN ORLEN is a leading company in the fuel and energy sector, one of the largest companies in Poland, and one with the highest overall brand value in the industry ${ }^{1}$. ORLEN Group operates six refineries and the region's largest network of service stations located in Poland, the Czech Republic, Germany and Lithuania. ORLEN processes crude oil into gasolines, diesel oil, fuel oil and aviation fuel. ORLEN is also a leading producer of petrochemicals, and its products are used as basic feedstocks by a large number of chemical companies.

Social responsibility for PKN ORLEN is basis for its operations and an important element of its business strategy. The company is gradually implementing long-term programmes, recognizing that business should be conducted in accordance with the needs of society, ethical standards and care for the natural environment. Table 2 presents the areas of the CSR strategy at PKN ORLEN.

Employees are the most important group of stakeholders for ORLEN. PKN ORLEN as the employer takes special care of those who contribute to the Company's value and commit to it for many years. ORLEN Group provides its staff with an opportunity to participate in a variety of activities which aim at integration and enhancing the sense of affiliation with the Company.

PKN ORLEN is active in various fields, supporting cultural development and cultural heritage protection initiatives, as well as programmes promoting environmental protection and sports. The Company is engaged in activities which aim at the conservation of Poland's national heritage. PKN ORLEN provides long-term support to the National Museum in Warsaw. What is more, the Company is one of the sponsors of the Foundation for Ignacy Lukasiewicz Memorial Museum of Oil Industry. Furthermore, ORLEN sponsors major Polish athletes who have successfully participated in European and World championships. One of Company's priorities is education. An example of ORLEN's commitment in this area is its

\footnotetext{
${ }^{1}$ This review of good practices has been prepared based on information available at PKN ORLEN Group websites, http://www.orlen.pl/EN/CSR/Pages/default.aspx, access: 25.11.2017.
} 
cooperation with Warsaw University of Technology and the School of Engineering and Social Sciences in Plock. Every year, at the academic year opening ceremony, the Company grants the "Awards of the PKN ORLEN's President" to students and academics for the best theses and research papers.

Table 2. Areas of the CSR Strategy at PKN ORLEN

\begin{tabular}{|c|c|c|}
\hline $\begin{array}{c}\text { CSR Strategy area } \\
\text { at PKN ORLEN }\end{array}$ & $\begin{array}{c}\text { CSR Strategy priorities at PKN } \\
\text { ORLEN }\end{array}$ & Premises \\
\hline Organization - we build relations & $\begin{array}{l}\text { - employee safety } \\
\text { - development and diversity mana- } \\
\text { gement } \\
\text { - life balance and social involve- } \\
\text { ment of employees }\end{array}$ & $\begin{array}{l}\text { - high awareness and expectations } \\
\text { towards the employer regarding } \\
\text { employee rights and safety } \\
\text { - generation Y as part of the work- } \\
\text { force with different expectations } \\
\text { towards the employer } \\
\text { - demographic changes, ageing po- } \\
\text { pulation } \\
\text { - employee expectations of more } \\
\text { participation in management and } \\
\text { dialogue with the employer, as } \\
\text { well as a chance to pursue social } \\
\text { causes }\end{array}$ \\
\hline $\begin{array}{l}\text { Close environment - we shape } \\
\text { attitudes }\end{array}$ & $\begin{array}{l}\text { - image of a responsible company } \\
\text { - stakeholders' involvement } \\
\text { - social involvement }\end{array}$ & $\begin{array}{l}\text { - low level of social trust, lack of part- } \\
\text { nership, involvement and coope- } \\
\text { ration } \\
\text { - growing awareness of consumers } \\
\text { who increasingly more often pay } \\
\text { attention to responsible conduct of } \\
\text { companies } \\
\text { - deepening social divide both at the } \\
\text { national, and global level }\end{array}$ \\
\hline $\begin{array}{l}\text { Distant environment - we are a } \\
\text { change leader }\end{array}$ & $\begin{array}{l}\text { - responsible development } \\
\text { - ethical leadership } \\
\text { - new business areas and innova- } \\
\text { tions }\end{array}$ & $\begin{array}{l}\text { - strong international social and } \\
\text { political pressure related to mi- } \\
\text { nimization of negative impact on } \\
\text { the environment } \\
\text { - development of new technologies } \\
\text { and their growing role in people's } \\
\text { lives } \\
\text { - increased public pressure to mea- } \\
\text { sure and reveal the effects of an } \\
\text { organization's activities, including } \\
\text { their environmental impact } \\
\text { - growing demand for energy }\end{array}$ \\
\hline
\end{tabular}

Source: Three areas of the CSR Strategy - response to trends, http://www.orlen.pl/EN/CSR/Pages/default.aspx, access: 25.11.2017.

PKN ORLEN is proud to set new trends. At the Company's Stop Cafe and Stop Cafe BISTRO, customers are offered Fairtrade-branded coffee, which implies that its suppliers comply with the rules of fair trade intended to put an end to exploitation of plantation workers. Customers can be sure that there was no child labour involved in the production process. In addition, ORLEN supports the World Land Trust organization, engaged in activities aimed at halting the destruction of South American rainforests. The coffee producer also cooperates with the Belgian Corporate Funding Programme organization which carries out projects designed to fight poverty in developing countries.

In December 2003, PKN ORLEN joined the Global Compact initiative launched by the Secretary General of the United Nations, Kofi Annan. The Company committed itself to respect ten principles related to human rights, labour, environment, and anti-corruption. 
Since 1997 PKN ORLEN is a member of the Responsible Care Programme. Responsible Care is the chemical industry's global initiative under which chemical companies work together to continuously improve their safety, health and environmental performance, and openly communicate their activities. What is more, the primary objective of the Programme is to change the negative image of products and manufacturing technology in chemical industry.

For the third year running, PKN ORLEN has been awarded the prestigious title of The World's Most Ethical Company by an international panel of experts at the US Ethisphere Institute (a global leader in defining and advancing the standards of ethical business practices). The title has been awarded since 2006 by a group of international experts in business ethics and good commercial practices. Experts select honorees on the basis of the Ethics Quotient rating system, which allows comprehensive verification of the capability of companies to apply ethical business practices in building their market position. In evaluating candidates, the experts consider such areas as corporate governance, social responsibility, building of human capital, efforts towards innovation.

\section{CONCLUSIONS}

Corporate social responsibility is an action strategy based on the principle of respecting the interests of all entities operating within the organization and in its environment, which benefits both the enterprise and the society as a whole.

The implementation of the CSR concept contributes to, among others, improving the company's image, enhancing contractors' trust and customer loyalty. Implementation of responsible business conduct standards also results in increased motivation and commitment of employees which translates into their greater creativity and efficiency. Good company reputation also impacts the perceived value of the company and leads to better cooperation with business partners, which in turn may lead to increased sales and boosts its competitive advantage (Leśna-Wierszołowicz 2016b).

Examples of good practices carried out at the PKN ORLEN Group are examples of how the concept of social responsibility can be implemented. The company is implementing longterm programmes which recognize that business must serve the needs of the society, comply with ethical standards and show a genuine care for the natural environment. The concept of corporate social responsibility is the bedrock of the company's business strategy. Activities undertaken by PKN ORLEN may serve as an example or inspiration for other organizations wanting to gain competitive advantage.

\section{REFERENCES}

Commission of the European Communities. 2001. Green Paper: Promoting a European framework for Corporate Social Responsibility. Brussels, Com. Eur. Com., 1-37.

Commission of the European Communities. 2002. Corporate Social Responsibility: A business contribution to Sustainable Development. Brussels, Com. Eur. Com., 5.

Čierna H. 2015. Corporate social responsibility and its theoretical solutions (process of ethical and social responsibility). Zesz. Nauk. PŚl., Ser. Organ. Zarz. 84, 50. 
Leśna-Wierszołowicz E. 2016a. Korzyści ze stosowania zasad społecznej odpowiedzialności biznesu $\mathrm{w}$ przedsiębiorstwie [The benefits of application of corporate social responsibility principles in a company]. Acta Sci. Acad. Ostrov., Sec. A 8(2), 66. [in Polish]

Leśna-Wierszołowicz E. 2016b. Społeczna odpowiedzialność biznesu jako element budowania przewagi konkurencyjnej [Corporate social responsibility as an element of building competitive advantage]. St. Pr. Wydz. Nauk Ekon. Zarządz. USzczec., Ser. Zarządzanie 43(1), 62. [in Polish]

Marcinkowska E., Sawicka J., Stronczek A. 2016. Społeczna odpowiedzialność biznesu jako koncepcja istotna dla funkcjonowania MŚP [Corporate social responsibility as the concept important for the functioning of small and medium-sized enterprises]. Stud. Ekonom. Zesz. Nauk. UE Katow. 299, 211. [in Polish]

Rak M. 2017. Corporate social responsibility (CSR) activities undertaken by enterprises. Ann. Market. Manag. Econom. SGGW. 3(1), 112.

Rok B. 2004. Odpowiedzialny biznes w nieodpowiedzialnym świecie. Warszawa, Akademia Rozwoju Filantropii w Polsce, 1-37. [in Polish]

Wykowski A. 2013. Społeczna odpowiedzialność biznesu gwarancją sukcesu przedsiębiorstwa [Corporate social responsibility as the guarantee of success of the enterprise]. Zesz. Nauk. Uniw. Przyr.-Hum. Siedl., Ser. Administr. Zarządz. 98, 293-294.

Żurek J. 2013. Społeczna odpowiedzialność przedsiębiorstwa tworzy nową jakość kultury przedsiębiorstwa [Corporate social responsibility creates a new quality of the company's culture]. Zesz. Nauk. UGdań., Stud. Mater. Inst. Transp. Handlu Mors. 10, 143.

Social environment, http://www.orlen.pl/EN/CSR/Pages/default.aspx, access: 25.11.2017.

Summary. The aim of the article is to present the concept of corporate social responsibility (CSR) as implemented by PKN ORLEN Group. The paper expounds the essence, dimensions and areas of CSR and benefits coming from the company's being a socially responsible organization. The paper is supplemented by a review of good practices undertaken by PKN ORLEN Group for which Corporate Social Responsibility is an essential element of business strategy. 